DOI: https://doi.org/10.31073/mivg202102-310

Available at (PDF): http://mivg.iwpim.com.ua/index.php/mivg/article/view/310

UDC 626.3

\title{
OPTIMAL OPERATION OF MULTIPURPOSE RESERVOIRS IN SERIES: ROSEIRES AND SENNAR CASE STUDY
}

\author{
T.Z. Saad Omer ${ }^{1}$, MSc student, S.E. Ahmed ${ }^{2}$, prof., A. Karimi ${ }^{3}$, assist. prof. \\ ${ }^{1}$ UNESCO Chair in Water Resources, Omdurman Islamic University, Khartoum, Sudan; \\ https://orcid.org/0000-0002-8671-9977; e-mail: thoaibazsaadomer@gmail.com: \\ ${ }^{2}$ UNESCO Chair in Water Resources, Omdurman Islamic University, Khartoum, Sudan; \\ https://orcid.org/0000-0002-5153-2475; e-mail: siddig57ahmed@gmail.com; \\ ${ }^{3}$ Civil \& Environmental Engineering Department, College of Engineering, National University of Science and Technology, \\ Muscat, Oman; \\ https://orcid.org/0000-0003-4250-2140; e-mail: akbarkarimi@nu.edu.om
}

\begin{abstract}
The Roseires-Sennar Dams System (RSDS) at lower part of Blue Nile River play a vital role in water supply to the irrigation schemes in Sudan. The existing rule curves for this system belong to 1925 and 1966 for Sennar and Roseires reservoirs, respectively. Introduction of new irrigation schemes, approved climate change impacts on Blue Nile River flow and upstream developments in Ethiopia as well as the heightening of the Roseires Dam from elevation 480 to 490 m.a.s.l have shown the RSDS is losing its efficiency in terms of fully supplying the water demands. The literature addresses the simulation of Roseires and Sennar dams, and tries to find the best coordinated rule curves through a limited number of operation rules to find optimal operating rules for reservoirs that minimize the impacts of new developments, water demand growth and climate change on water supply to various demands on Blue Nile River. Such decisions are locally optimal in best condition since they do not consider the storage and carry-over capability of reservoirs that can transfer the non-optimal (locally optimal) decisions to other time steps of planning horizon and creat shortages in other time steps. Therefore, aim of this research is to find optimal coordinating operation rules for Roseires and Sennar dams that through a non-linear multi-period optimization model that considers the conditions of climate change, flow regime and water demand as scenarios. Model is validated by comparison with observed reservoir operation during November 1999 till May 2000. Eighteen scenarios that cover the normal, dry and very dry flow regimes, along with three suggested crop patterns and climate change impact are analyzed. Results shows in normal conditions of flow, crop pattern 2 is the most recommended with more than 11 Billion USD marginal profit and fully supplying the water demand and $1530 \mathrm{GWh}$ energy generation per annum. The coordinated rule curves have a totally different pattern of emptying and filling compared with existing ones. Rule curves change from one flow regime to another, which proves how change in conditions of the system has influence on optimal operation rules. Comparison of marginal profits with crop pattern 2 shows in three inflow conditions of normal, dry and very dry years multi-period optimization model could keep the marginal profits above 11 Billion USD, let's say, 11,050, 11,056 and 11,042 Billion USD, respectively, which shows the robustness of model in dealing with all conditions and keeping the marginal profits not affected. However, the Roseires rule curves are different in these three condition, while Sennar rules curves are almost the same. Without climate change impact, model can manage to supply the water demands fully in all flow conditions. However, water supply reliability is affected by climate change with all crop patterns. Roseires-Sennar Dams system in a normal year under climate change can produce 10,688 Billion USD marginal profit and 1371 GWh per year energy. It shows that model could manage the system performance so that climate change decrease the marginal profit by 3.27\%, while inflow is reduced by $25 \%$ and water demands and evaporation increased by $19 \%$. Energy generation under climate change has decreased by 10,5\%, which is the most affected sector. Crop pattern 2 and 3 are not suitable for climate change conditions since up to $65 \%$ deficit in water supply can happen if very dry year realizing with climate change. In very dry conditions crop pattern 1 is more suitable to be practiced.
\end{abstract}

Keywords: Roseires - Sennar Dam, Reservoir Operation, Optimal Coordination, Multi-purpose Reservoir, Long-term Planning

Introduction. The Roseires and Sennar Dams have been operating according to a certain plan. The existing coordination plan states during June to September keep the reservoirs as empty as possible for flood control at level of 467 m.a.s.1 and 417.5 m.a.s.1 for Roseires and
Sennar Dams, respectively (Abdelatif; 2004). According to this coordination plan September and October based on the flow at ElDeim Station is the filling time, all sluice gates must be kept open and if flow at ElDeim is above $350 \mathrm{MCM} /$ day then additional flow will be stored. This 
process continues for 45 days until level of water surface reaches $421.7 \mathrm{~m}$ and $490 \mathrm{~m}$ for Sennar and Roseires Dams, respectively. The level of water is maintained after this till the time flow at ElDeim starts to fall below the water demand, when the reservoirs are emptied (Abdelatif; 2004). The Roseires Dam specification such as height, capacity and surface area have changed since 2013 to $490 \mathrm{~m}, 7400 \mathrm{MCM}$ and $700 \mathrm{Km}^{2}$, so the new level of $490 \mathrm{~m}$ is also considered in the rule curve explained above. Figure 1-1 shows observed operation of both dams in existing coordination plan that has shortage in June, September to October from $30 \%$ up to $67 \%$. The existing rule curves for Roseires-Sennar dams' system (RSDS) are not necessarily efficient for coordination of these two dams anymore because of the following reasons:

1. Roseires Dam capacity and specifications has changed since 2013. Therefore, a new plan of reservoir operation is required to assure the efficient fulfillment of reservoir operation goals for Roseires and Sennar dams after 2013 (Wikipedia; 2020, SMEC; 2019).

2. Considering the Roseires Dam specifications change, hydrologic uncertainty can make the operation rule before 2013 totally ineffective especially in dry years or at severe droughts. In 1913 the annual flow reduced by $60 \%$ compared with long-term average of $49625 \mathrm{MCM}$ and, in 1972 and 1984 the flow reduced by 40\%. A drought period was prevailing in the Blue Nile for 10 years 1978 till 1988 (Nile Basin Initiative 2017). In such conditions special operation policy must be adopted to minimize the impacts of drought on reservoir operation efficiency.

3. Water demand growth due to development in agriculture can also make this rule ineffective by addition of new schemes as mentioned above. $1,061,000$ ha will be added to existing irrigation schemes of Blue Nile at downstream of Roseires and Sennar dams, which will increase the irrigation demand significantly in future (Basheer et al.; 2018).

4. Climate change also can make this rule ineffective by changing the hydrological characteristics of the flow and even influencing the existing and future evapotranspiration and irrigation demand. Recent studies found that Blue Nile riverbasin will face $21.3 \%$ increase in sediment load, $19 \%$ of evapotranspiration increase and $25 \%$ of rainfall reduction till 2080 (Gelete et al. 2019).

5. Combination of the four above factors can make the existing operation rule, which may have been suitable before 2013, completely ineffective in new conditions.
Therefore, in this research coordinated operation of Roseires and Sennar Dam will be modeled and optimized while considering all five conditions mentioned above. To obtain optimal operation rules a multi-period multi-reservoir optimization model will be developed that uses the linear programming to obtain the optimal operation rules for coordinated operation of both dams. Aim of this research is to evaluate effect of optimal coordinated operation of Roseires and Sennar Dams on water supply to existing and future irrigation schemes as well as energy generation and marginal profit in the system. This study is concerned with the operation and control of multi-purpose reservoirs systems taking Roseires - Sennar reservoirs- operating in series - as case study. The problem involves finding appropriate release decisions from various reservoirs in the system in order to satisfy the multiple objectives which may be conflicting. The specific objectives of the study are:

1. Developing an optimal multi-period reservoir operation model for Roseires \&Sennar reservoirs.

2. Identifying the factors affecting reservoirs' operation through model analysis

3. Generating appropriate release decisions for the two reservoirs to satisfy the conflicting objectives between water for irrigation, hydropower generation and other uses.

Developing a multi-period optimization model (MOM) for Roseires-Sennar Dams' reservoirs operation: This model will determine the optimal release and storage of water from dams as well as allocation to irrigation schemes and energy generation to have the optimal cumulative marginal profit over the analysis horizon. The Roseires and Sennar Dams will be included in a Non-linear optimization model for reservoir operation. The irrigation water demand will be lumped for each dam. Therefore, although 12 irrigation schemes will be considered but they will be lumped in model as only two demands for Roseires and Sennar dams, respectively. The inflow to the reservoirs is only the monthly inflow measured at ElDeim station. The modeling is based on water balance in dams and demand balance equations. In the objective function marginal profit of irrigation (the irrigation schemes) and energy generation are considered as economic indices of the system to be maximized. Return flow from irrigation schemes to the Blue Nile River is not considered in this research due to data availability, which is on the safe side or will be conservative. Model is monthly and for a multi-year horizon that can vary from 1 year to 100 year. Model is basically deterministic and 
it does not consider the uncertainty explicitly in model parameters. Uncertainty of future conditions will be considered through the 18 scenarios that exemplify the concerns of the stakeholders as well as hydrologic and climate change conditions.

Literature Survey. Reservoir operation is an old topic in water resources management, which goes back to 1883 where W. Rippl introduces the mass curve method for reservoir capacity sizing (Rippl; 1883). In the mass curve method the demand is assumed constant or called safe yield. Other method for reservoir operation that over comes the limitation of Rippl method is Sequent Peak Method that considers demand variation over the months or years and finally will give the minimum reservoir capacity along with reservoir operation plan (Thomas and Burden; 1963). The Standard Operation Policy (SOP) is another reservoir operation model that uses the reservoir simulation for a single-reservoir (Maas et al.; 1962, Loucks et al.; 1981). SOP is blind to future impacts of current decision on reservoir operation in terms of large deficits due to emptying the reservoir before dry months or years (You and Cai; 2008). Therefore, Hedging Rules were introduced that try to distribute the deficits to avoid a large deficit in the future (Bower et al.; 1962, Kelemes 1977, Loucks et al.; 1981). As development of waterbasin moved on from 1950's and more reservoirs are made at upstream areas, these approaches proved to be not efficient enough to deal with a network of reservoirs instead of a single reservoir. The process of effective use of such rules will become more complicated since any change in one rule requires an adjustment of other reservoirs operation rule that by considering the huge number of possible combinations it will become a very complicated task and finally use of such rules in a network of reservoirs will not lead to an effective reservoir operation performance. Therefore, method of mathematical programming is used for obtaining more efficient, dynamic and robust reservoir operation rules (Loucks et al.; 1967, Thomas and Revelle; 1966, Manne; 1962). The important feature of mathematical programming is consideration of complicated spatial and temporal interactions within the reservoir network and optimizing their operation to achieve the system goal or goals. The optimization method is applied to different applications of rules in reservoir systems in the literature. Optimization of rule curves, like hedging rules. In this case usually evolutionary algorithms are used, like GA (Oliviera and Loucks 1997; Karnatapu et al. 2019).

Optimization of a reservoir network by single-period optimization which is used in most of commercial softwares such as WEAP, MODSIM, RiverWare, MIKEBasin, RIBASIM and HECReSIM (Close et al. 2003; Lucas 2018; Shafer and Labadie 1978; Charalampos et al. 2015; Ngo et al. 2016; Ortiz-Partida et al. 2016). The third class of optimization application is for multi-period optimization of reservoir networks, which is the method to be used in this research, too (Cai et al. 2001a, Cai et al. 2001b, Cai et al. 2003, Schluter et al. 2005, Seifi and Hipel 2001, Pallottino et al. 2005). Actually, upstream development and climatic changes made meaningful variations in river flow regimes, where the flow regime in next time steps for a downstream reservoir will be affected with more factors compared with 1990's, where only one or two factor could be identified. The multiperiod multi-purpose reservoir operation models can cope with a huge number of factors that affect the flow regime and availability temporally and spatially. This approach is able to integrate different disciplines or factors and produce an optimum decision where all stakeholders are considered and benefit from it (Cai et al. 2003). In a research on eastern Nile basin, HECResSIM, which uses a single-period optimization model, is used to evaluate the cumulative impacts of basin development on downstream water users. It is used for different operation scenarios development to be evaluated under different climatic conditions (Belachew and Mekonen 2014). Blue Nile River Basin riparian countries Sudan and Ethiopia have agreed to collaborate in development of its water resources for sustainable socio-economic growth. Blue Nile has high potentiality for hydropower and irrigation development. However, impacts of upstream development on downstream are not well studied. McCarteny modeled the Blue Nile resources system by WEAP for studies of upstream development on downstream. The model represents the current and the future state of the Blue Nile Riverbasin system according to the basin master plan. WEAP analysis predicts that upstream development in Ethiopia will decrease the flow in Khartoum in wet season, while the flow during January to May increase due to flow regulations (McCarteny et. Al. 2009).

Blue Nile System including Roseires, Sennar and GERD dams are simulated to understand what will be quantified value of cooperation in a trans-boundary riverbasin (Basheer et al. 2018). Efficient utilization of the limited Water, Energy, and Food (WEF) resources in stressed transboundary river basins requires understanding their interlinkages in different transboundary cooperation conditions. The Blue Nile Basin, a transboundary river basin between Ethiopia 
and Sudan, is used to illustrate the impacts of cooperation between riparian countries on the Water-Energy-Food nexus (WEF nexus). These impacts are quantified and evaluated using a daily model that simulates hydrological processes, irrigation water requirements, and water allocation to hydro-energy generation and irrigation water supply. Satellite-based rainfall data are evaluated and applied as a boundary condition to model the hydrological processes. The model is used to determine changes in the long-term economic gain (i.e. after infrastructure development plans are implemented and in steady operation) for each of Sudan and Ethiopia independently, and for the Blue Nile Basin from WEF in 120 scenarios. Those scenarios result from combinations of three cooperation states: unilateral action, coordination, and collaboration; and infrastructure development settings including the Grand Ethiopian Renaissance Dam and planned irrigation schemes in Sudan. The results show that the economic gain of the Blue Nile Basin from WEF increases with raising the cooperation level between Ethiopia and Sudan to collaboration. However, the economic gain of each riparian country does not necessarily follow the same pattern as the economic gain of the basin (Basheer et al. 2018).

Study Area. The study area for this research is the Roseires and Sennar Dam system shown in Figure 1 . The water resources is mainly the flow

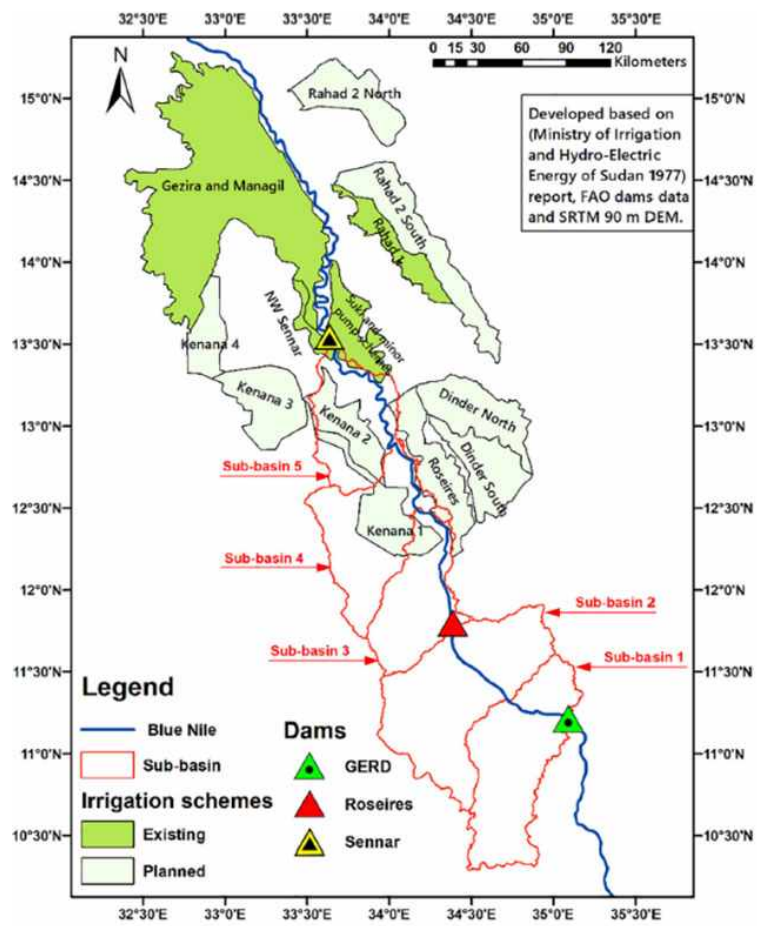

Figure 1. The study area for this research

(Basheer et al. 2018) at ElDeim station and other tributary flows or even return flows from irrigation schemes are not considered for this study due to data accuracy and availability. The irrigation schemes considered here are 9 future schemes and 4 existing schemes, which are shown in Figure 2 and details of them are shown in Table 1. Figure 3 shows the observed historical flow at ElDeim station from 1914 till 2017.

Details of existing and future irrigation schemes are shown in Table 1, where 6 schemes are existing and 9 schemes are to be developed in future. Three crop patterns are considered for these irrigation schemes, existing and future, that their income margin, water demand and total area are shown in Table 2. Based on this Table 2, crop pattern 2 where $39 \%$ is sugarcane, $28 \%$ cotton and $22 \%$ Sesame has the highest water demand and marginal profit.

Roseires and Sennar dams' specification used in this research are shown in Table 3. Figure 4, shows the existing rule curves of the Roseires and Sennar Dam. June to September both reservoir must be at minimum level. May is emptying and October is filling time. The rest of year also both reservoirs are kept full. This rule curves resulted into $67 \%$ shortages for Gazira and Managil in some months (Herve Plusquellec; 1990). Existing rule curves are used for comparison with rule curves the multi-period optimization model will generate for coordinated operation of both reservoirs.

Methodology. The methodology outline is shown in Figure 5, where model and scenarios development part of it will be explained in this section. Other parts of the outline are already covered in previous sections. Figure 6 shows

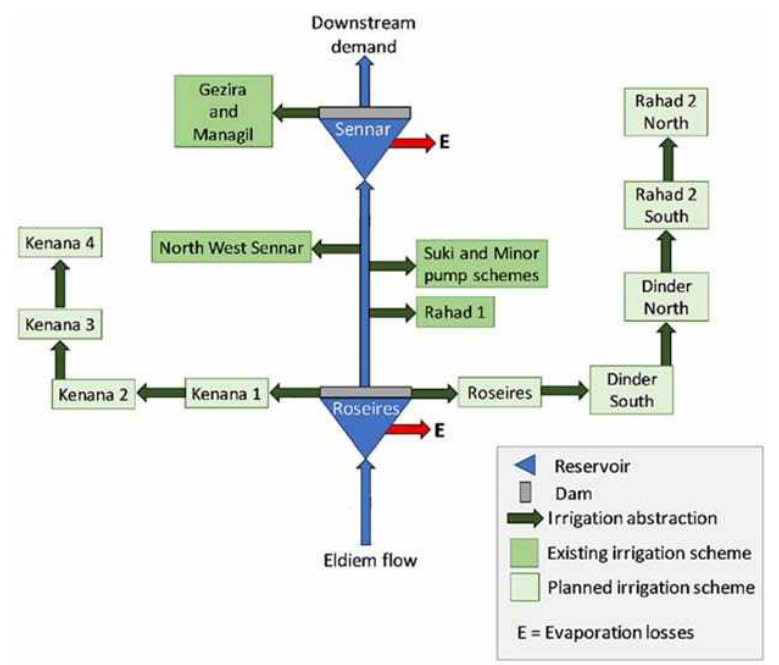

Figure 2. The conceptual model of RoseiresSennar Dam system (Basheer et al. 2018) 
1. Irrigation schemes details

\begin{tabular}{|l|c|c|c|}
\hline \multicolumn{1}{|c|}{ Irrigation Scheme } & Total Area ha & Dam & Status \\
\hline Suki & 36500 & Roseires & Existing \\
\hline Rahad 1 & 168037 & Roseires & Existing \\
\hline Upstream Sennar & 117626 & Roseires & Existing \\
\hline Gezira \& Managil & 1093502 & Sennar & Existing \\
\hline North West Sennar & 21000 & Roseires & Existing \\
\hline Rahad 2 & 268000 & Roseires & Future \\
\hline South Dinder & 168000 & Roseires & Future \\
\hline Kenana 1,2,3,4 & 456000 & Roseires & Future \\
\hline Roseires & 123000 & Roseires & Future \\
\hline Dinder South & 48000 & Roseires & Future \\
\hline
\end{tabular}



Figure 3. Monthly flow time series 1914-2017

2. Crop pattern scenarios information

\begin{tabular}{|l|c|c|c|c|c|c|c|}
\hline \multirow{2}{*}{ Supplying Dam } & \multirow{2}{*}{$\begin{array}{c}\text { Total } \\
\text { Area ha }\end{array}$} & $\begin{array}{c}\text { Income \$/ } \\
\text { MCM }\end{array}$ & $\begin{array}{c}\text { WR } \\
\text { BCM }\end{array}$ & $\begin{array}{c}\text { Income \$/ } \\
\text { MCM }\end{array}$ & $\begin{array}{c}\text { WR } \\
\text { BCM }\end{array}$ & $\begin{array}{c}\text { Income \$/ } \\
\text { MCM }\end{array}$ & $\begin{array}{c}\text { WR } \\
\text { BCM }\end{array}$ \\
\hline Roseires Existing & 343163 & 243000 & 3.261 & 433000 & 3.834 & 320000 & 3.367 \\
\hline $\begin{array}{l}\text { Sennar Existing } \\
\text { \& Future }\end{array}$ & 1093502 & 243000 & 10.392 & 433000 & 12.218 & 320000 & 10.731 \\
\hline Roseires Future & 1404163 & 293011 & 10.008 & 421309 & 13.346 & 345006 & 10.701 \\
\hline
\end{tabular}

3. Roseires and Sennar Dam specifications

\begin{tabular}{|l|c|c|}
\hline \multicolumn{1}{|c|}{ Reservoir/Dam Specifications } & Roseires & Sennar \\
\hline Max. Capacity MCM & 7400 & 640 \\
\hline Minimum Operational Capacity MCM & 50 & 220 \\
\hline Max. Level meter & 490 & 421.7 \\
\hline Minimum Operational Level meter & 469 & 417.2 \\
\hline Turbine Headloss m & 1.5 & 0.3 \\
\hline Minimum Downstream flow Requirement MCM/month & $* * * * * *$ & 150 \\
\hline Leakage MCM/Day & $* * * * * *$ & 0.2 \\
\hline Year of operation & 1966 & 1925 \\
\hline Lake Area Km ${ }^{2}$ & 627 & 194 \\
\hline Installed Power MW & 280 & 15 \\
\hline Existing Irrigated Area ha & 343,163 & $1,093,502$ \\
\hline Max Release Capacity MCM/Month & 44,064 & 45,619 \\
\hline
\end{tabular}






Figure 4. Existing Roseires and Sennar reservoirs' rule curves
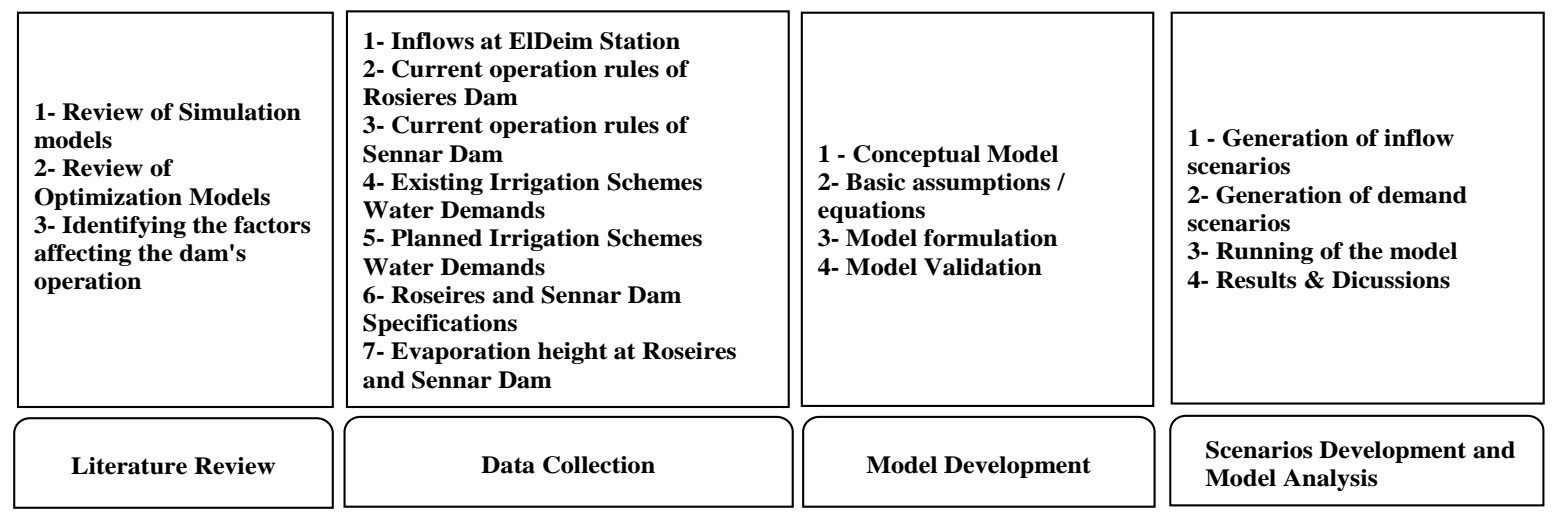

Figure 5. Methodology Outline for this research

the conceptual model for Roseires-Sennar Dam system (RSDS). In this model all the irrigation schemes their supply is from Roseires reservoir release are lumped as one demand node with summation of all water demands. Evaporation and spillage are considered. Released water also can be used for energy generation as much as the turbine system capacity allows. Return flows from irrigation schemes and tributary flows are not included in this model due to their complexity, data availability and also to keep the model in more conservative side. Outflow of the RSDS will flow at downstream of the Sennar Dam towards Khartoum. Minimum flow considered for this downstream demand is $150 \mathrm{MCM}$ per month (ElAmin M.; 2006).

The algorithm of the model analysis in Figure 7 shows how model is run for each scenario and its results are stored and used later for selection of best scenario. To select the best scenario, marginal profit, water supply ratio and energy generation can be considered as factors for ranking of the scenarios and selection of best crop pattern and rule curve. Model mathematical formulation is shown in equations 1 to 19 . This system of equations shows a non-linear multi-period optimization model where is setup on monthly time steps for multiple years. The objective function of the model is annual marginal profit and model is constrained to have end of period storage equal to initial storage (equations 10 and 11), where it is important for reservoir operation. Energy generation equations are non-linear and play an important role in reservoir operation since the reservoir release and storage are coupled in this equation. River flow , $\mathrm{RF}_{1, \mathrm{y}, \mathrm{m}}$, is flowing into Sennar reservoir and showing the interaction between Roseires and Sennar reservoirs. This model now considers important factors, upstream-downstream interaction by, $\mathrm{RF}_{1, \mathrm{y}, \mathrm{m}}$, energy generation, water supply, downstream minimum flow requirement and marginal profit, which are the main features to be considered in a coordinated operation where all stakeholders benefits are considered. Other important equations of the model are 17 and 19, where lower limit and upper limit on river flow is imposed. Lower limit of $150 \mathrm{MCM}$ per month is the minimum downstream flow requirement, especially after Sennar Dam (ElAmin 2006) and 19620 MCM per month as the upper limit is the safe flow in Blue Nile so that flooding will 




Figure 6. The conceptual model for Roseires-Sennar Coordinated Reservoir Operation

not happen (Abdo et al. 2005). In this model equations 4 and 7 show the water available for allocation to irrigation schemes. Release from Roseires or Sennar is logically more than water for allocation to irrigation since released water is also for downstream uses as well as irrigation. Parameters and variables of this model are explained in the Table 4.

This model which is a non-linear optimization model is programmed and solved in General Algebraic Modeling System (GAMS www. gams.com) by MINOS solver. To apply this model for the analysis of Roseires-Sennar Dam System scenarios are considered, which reflect future climatic and hydrologic conditions and also suggested conditions for irrigation schemes in Table 5. These 9 scenarios will be considered also with climate change that increase the water requirement by $19 \%$, reservoir evaporation by $19 \%$ and reduce the inflow by $25 \%$ to make 9 more scenarios to consider totally 18 scenarios. Results of analyzing these scenarios are presented and discussed in next section.

Results and Discussion. In this section results of model analysis will be presented, where first

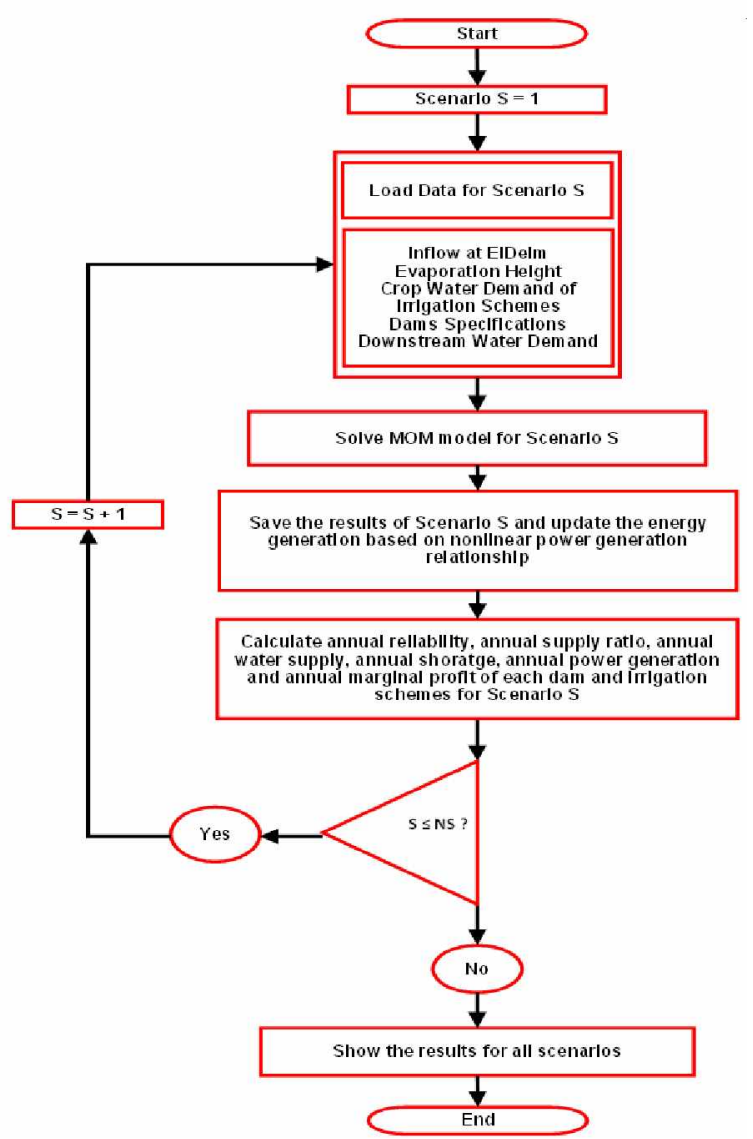

Figure 7. Algorithm of model analysis for coordinated optimal operation of Roseires and Sennar Dam

validation of model will be discussed and later the results of model analysis for 18 scenarios. Model validation is an important process of model application, which is done for observed Roseires and Sennar operation during Nov-1999 till Oct-2000 as shown in Figures 8 and 9.

Figure 8 shows that model operate the Roseires reservoir to store more water while supplying the water demand fully. More water storage has important implications for energy generation and reservoir operation since model is multi-period and has knowledge of future till Oct-2000, decides in a more efficient way about how much water to store and how much to release. The same idea applies to Sennar reservoir operation by model in Figure 9 , where storage and release is coordinated with Roseires reservoir operation and storage follows the pattern of water demand and release also follows the same pattern, while by more storage of water energy generation also benefit from it. In observed operation of Sennar reservoir which follows the existing rule curve, reservoir is emptied in May and is kept empty in rest of year so it can not use the flow or storage potential for energy generation, since before April low flow months are there and in June 
4. Parameters and variables definition for mathematical model of Roseires and Sennar Dam

\begin{tabular}{|c|c|c|}
\hline $\operatorname{Max} . Z-\Sigma_{y} M P_{y}$ & Objective Function Annual Marginal Profit & $(1)$ \\
\hline \multicolumn{3}{|l|}{ Subject to: } \\
\hline $\mathrm{S}_{1, \mathrm{y}, \mathrm{m}}+\mathrm{Q}_{1, \mathrm{y}, \mathrm{m}}-\mathrm{Ev}_{1, \mathrm{y}, \mathrm{m}}-\mathrm{R}_{1, \mathrm{y}, \mathrm{m}}-\mathrm{Sp}_{1, \mathrm{y}, \mathrm{m}}=\mathrm{S}_{1, \mathrm{y}, \mathrm{m}+1}$ & Roseires Reservoir Water Balance Equation & $(2)$ \\
\hline $\begin{array}{l}\mathrm{S}_{2, \mathrm{y}, \mathrm{m}}+\mathrm{RF}_{2, \mathrm{y}, \mathrm{m}}+\mathrm{Q}_{2, \mathrm{y}, \mathrm{m}}-\mathrm{Ev}_{2, \mathrm{y}, \mathrm{m}}-\mathrm{Rl}_{2, \mathrm{y}, \mathrm{m}}- \\
-\mathrm{Sp}_{2, \mathrm{y}, \mathrm{m}}=\mathrm{S}_{2, \mathrm{y}, \mathrm{m}+1}\end{array}$ & Sennar Reservoir Water Balance Equation & (3) \\
\hline $\mathrm{R}_{1, \mathrm{y}, \mathrm{m}} \geq \mathrm{WA}_{1, \mathrm{y}, \mathrm{m}}$ & $\begin{array}{l}\text { Available water for allocation at Roseires } \\
\text { Downstream }\end{array}$ & (4) \\
\hline $\mathrm{WA}_{1, \mathrm{y}, \mathrm{m}}+\mathrm{WASL}_{1, \mathrm{y}, \mathrm{m}} \geq \mathrm{D}_{1, \mathrm{y}, \mathrm{m}}$ & $\begin{array}{l}\text { Water demand balance equation at Roseires } \\
\text { Downstream }\end{array}$ & $(5)$ \\
\hline $\mathrm{R}_{1, \mathrm{y}, \mathrm{m}}+\mathrm{Sp}_{1, \mathrm{y}, \mathrm{m}}=\mathrm{WA}_{1, \mathrm{y}, \mathrm{m}}+\mathrm{RF}_{1, \mathrm{y}, \mathrm{m}}$ & Water Balance in Roseires Reservoir Downstream & $(6)$ \\
\hline $\mathrm{R}_{2, \mathrm{y}, \mathrm{m}} \geq \mathrm{WA}_{2, \mathrm{y}, \mathrm{m}}$ & $\begin{array}{l}\text { Available water for allocation at Sennar } \\
\text { Downstream }\end{array}$ & $(7)$ \\
\hline $\mathrm{WA}_{2, \mathrm{y}, \mathrm{m}}+\mathrm{WASL}_{2, \mathrm{y}, \mathrm{m}} \geq \mathrm{D}_{2, \mathrm{y}, \mathrm{m}}$ & $\begin{array}{l}\text { Water demand balance equation at Sennar } \\
\text { Downstream }\end{array}$ & $(8)$ \\
\hline $\mathrm{R}_{2, \mathrm{y}, \mathrm{m}}+\mathrm{Sp}_{2, \mathrm{y}, \mathrm{m}}=\mathrm{WA}_{2, \mathrm{y}, \mathrm{m}}+\mathrm{RF}_{2, \mathrm{y}, \mathrm{m}}$ & Water Balance in Sennar Reservoir Downstream & $(9)$ \\
\hline $\mathrm{S}_{1, \mathrm{y}, 1}=\mathrm{S}_{1, \mathrm{y}, 13}$ & $\begin{array}{l}\text { This equation enforces initial storage be equal } \\
\text { to final storage, which is important in reservoir } \\
\text { operation since you are sure at the }\end{array}$ & $(10)$ \\
\hline $\mathrm{S}_{2, \mathrm{y}, 1}=\mathrm{S}_{2, \mathrm{y}, 13}$ & End of year you are at the same level that you start & $(11)$ \\
\hline $\mathrm{Ev}_{1, \mathrm{y}, \mathrm{m}}=\mathrm{e}_{1, \mathrm{y}, \mathrm{m}} \times\left[\mathrm{f}_{1}+\mathrm{f}_{1}^{\prime} \times\left(\mathrm{S}_{1, \mathrm{y}, \mathrm{m}}+\mathrm{S}_{1, \mathrm{y}, \mathrm{m}+1}\right)\right]$ & Evaporation volume from Roseires Reservoir & $(12)$ \\
\hline $\mathrm{Ev}_{2, \mathrm{y}, \mathrm{m}}=\mathrm{e}_{2, \mathrm{y}, \mathrm{m}} \times\left[\mathrm{f}_{2}+\mathrm{f}_{2}^{\prime} \times\left(\mathrm{S}_{2, \mathrm{y}, \mathrm{m}}+\mathrm{S}_{2, \mathrm{y}, \mathrm{m}+1}\right)\right]$ & Evaporation volume from Sennar Reservoir & $(13)$ \\
\hline $\begin{array}{l}\mathrm{En}_{1, \mathrm{y}, \mathrm{m}}=\mathrm{F} \times \mathrm{h}_{1} \times \mathrm{g} \times \mathrm{R}_{1, \mathrm{y}, \mathrm{m}} \times\left(\mathrm{g}_{1}+\right. \\
\left.\mathrm{g}^{\prime} \times \mathrm{S}_{1, \mathrm{y}, \mathrm{m}}-\mathrm{HL}_{1}\right)\end{array}$ & Energy generation of Roseires Reservoir & $(14)$ \\
\hline $\begin{array}{l}\mathrm{En}_{2, \mathrm{y}, \mathrm{m}}=\mathrm{F} \times \mathrm{h}_{2} \times \mathrm{g} \times \mathrm{R}_{2, \mathrm{y}, \mathrm{m}} \times\left(\mathrm{g}_{2}+\right. \\
\left.\mathrm{g}_{2}{ }_{2} \times \mathrm{S}_{2, \mathrm{y}, \mathrm{m}}-\mathrm{HL}_{2}\right)\end{array}$ & Energy generation of Sennar Reservoir & $(15)$ \\
\hline $\operatorname{SMin}_{1} \leq \mathrm{S}_{1, \mathrm{y}, \mathrm{m}} \leq \operatorname{SMax}_{1}$ & $\begin{array}{l}\text { Upper and Lower Limit of Roseires reservoir } \\
\text { operation }\end{array}$ & $(16)$ \\
\hline $150 \leq \mathrm{RF}_{1, \mathrm{y}, \mathrm{m}} \leq 19620$ & $\begin{array}{l}\text { Upper and Lower Limit on reservoir release (Lower } \\
\text { limit is minimum downstream flow requirement } \\
\text { and upper limit is maximum flow in normal year as } \\
\text { an indication of safe river flow in Blue Nile) }\end{array}$ & $(17)$ \\
\hline $\operatorname{SMin}_{2} \leq \mathrm{S}_{2, \mathrm{y}, \mathrm{m}} \leq \mathrm{SMax}_{2}$ & $\begin{array}{l}\text { Upper and Lower Limit of Sennar reservoir } \\
\text { operation }\end{array}$ & $(18)$ \\
\hline $150 \leq \mathrm{RF}_{2, \mathrm{y}, \mathrm{m}} \leq 19620$ & $\begin{array}{l}\text { Upper and Lower Limit on reservoir release (Lower } \\
\text { limit is minimum downstream flow requirement } \\
\text { and upper limit is maximum flow in normal year as } \\
\text { an indication of safe river flow in Blue Nile) }\end{array}$ & $(19)$ \\
\hline
\end{tabular}

where:

$r, y, m-\mathrm{r}$ is index for dams, $\underline{1}$ is for Roseires and 2 is for Sennar. $m$ is index for month and $y$ is index for year.

$D_{r, y, m}$ - Monthly water demand of irrigation schemes to be supplied from Roseires Dam if $r=1$ and from Sennar Dam if $r=2$. (MCM)

$e_{1, y, m}-$ Monthly evaporation height from each reservoir (mm)

$E n_{r y m}$ - Monthly energy generated by each reservoir (GWh)

$E v_{r y m}$ - Monthly evaporation volume from reservoirs (MCM)

$F$ - Conversion factor in energy equation to change power to monthly energy $f_{r}$ - Coefficient in linearizing the Area-Volume relationship for reservoirs

$f_{r}^{\prime}-$ Unknown factor in linearizing the Area-

Volume relationship for reservoirs

$g_{r}$ - Coefficient in linearizing the Elevation-

Volume relationship for reservoirs

$g_{r}{ }_{r}$ - Coefficient in linearizing the Elevation-

Volume relationship for reservoirs

$H L_{r}$ - Turbine Headloss for each reservoir (m)

$H \mathrm{Max}_{r}$ - Maximum Level in each reservoir (m)

$M P_{y}-$ Annual Marginal Profit (\$)

$Q_{r y m}-$ Tributary flow to the Roseires or Sennar

Dam. If $r=1$ then it is flow at ElDeim Station. If

$\mathrm{r}=2$ then it is tributary flow to Sennar Dam, which is assumed 0 in this research. (MCM) 
$R_{r, y, m}$ - Monthly release from reservoirs (MCM)

$R F_{r, y, m}$ - Monthly Blue Nile River flow at downstream of Roseires Dam if $\mathrm{r}=1$ and at downstream of Sennar Dam if $r=2$. (MCM)

$R \operatorname{Max}_{r}$ - Maximum Monthly Release for each reservoir (MCM)

$S_{r, y, m}-$ Reservoir Monthly Storage (MCM)

$S M^{2} x_{r}$ - Maximum Capacity of each reservoir (MCM)

$S \mathrm{Min}_{r}-$ Minmum Operational Storage of each reservoir $(\mathrm{MCM})$
$S p_{r, y, m}$ - Monthly spillage from reservoirs (MCM)

$W A_{r y m}$ - Monthly available water for allocation from each reservoir (MCM)

$W A S L_{r y m}$ - Monthly deficit if water supply to irrigation demand (MCM)

$Z$ - Cumulative Marginal Profit of the Roseires-Sennar Dam System for the whole planning period $(\$)$

$\gamma$ - Specific weight of Water $9810 \mathrm{~N} / \mathrm{m}^{3}$

$\eta_{\mathrm{r}}-$ Turbine Efficiency for each dam, considered $90 \%$ as default

5. Scenarios made for analysis by

\begin{tabular}{|l|c|c|}
\hline \multicolumn{1}{|c|}{ Flow Condition } & Crop Patterns & Scenarios \\
\hline \multirow{2}{*}{ NY - Normal Year, 50\% Exceedance - 1973 } & CP1 & S1 \\
\cline { 2 - 3 } & CP2 & S2 \\
\cline { 2 - 3 } & CP3 & S3 \\
\hline \multirow{2}{*}{ DY - Dry Year, 75\% Exceedance - 1965 } & CP1 & S4 \\
\cline { 2 - 3 } & CP2 & S5 \\
\cline { 2 - 3 } & CP3 & S6 \\
\hline \multirow{2}{*}{ VDY - Very Dry Year, 80\% Exceedance - 1980 } & CP1 & S7 \\
\cline { 2 - 3 } & CP2 & S8 \\
\cline { 2 - 3 } & CP3 & S9 \\
\hline
\end{tabular}

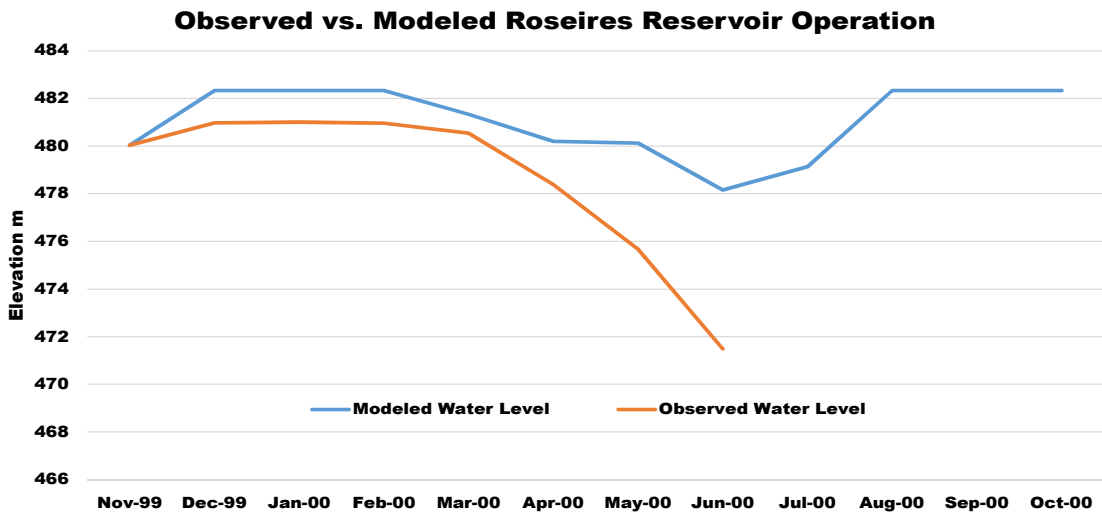

Figure 8. Roseires reservoir operation

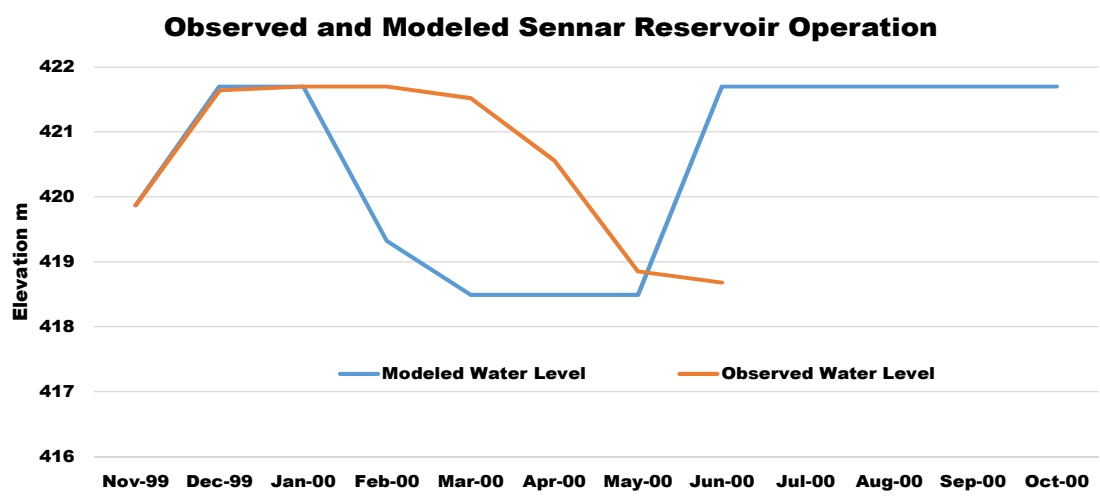

Figure 9. Sennar reservoir operation 


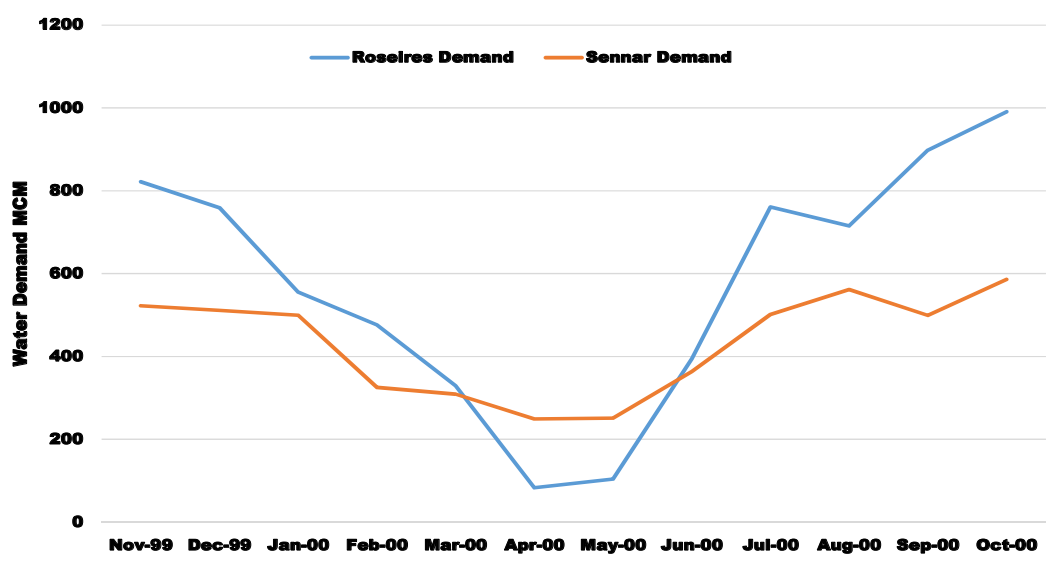

Figure 10. Water demand to be supplied from each dam

where high flows occur reservoir is kept empty. In coordinated operation more water is stored in Roseires, by emptying the Roseires less while considering flood constraint and letting Sennar make use of water flow and reservoir storage as much as possible for water supply and energy generation. It is clear from this validation run of the model that coordinated reservoir operation for Roseires-Sennar Dam system operated the system with a clear more efficiency in resources utilization, which is expected from a multi-period optimization model.
After validation process, how scenarios are made will be explained through the figures 11 and 12. Figure 11 shows the selected inflow scenarios, which exemplify the Normal, Dry and Very Dry years in Blue Nile River at ElDeim station. The years 1973, 1965 and 1980 are exemplifying the Normal, Dry and Very Dry years in Blue Nile River. Annual flow for each inflow scenario is $48902 \mathrm{MCM}, 43365 \mathrm{MCM}$ and $42679 \mathrm{MCM}$ according to Normal, Dry and Very years. For water demands, as mentioned before three crop patterns are considered that include 7 crops within

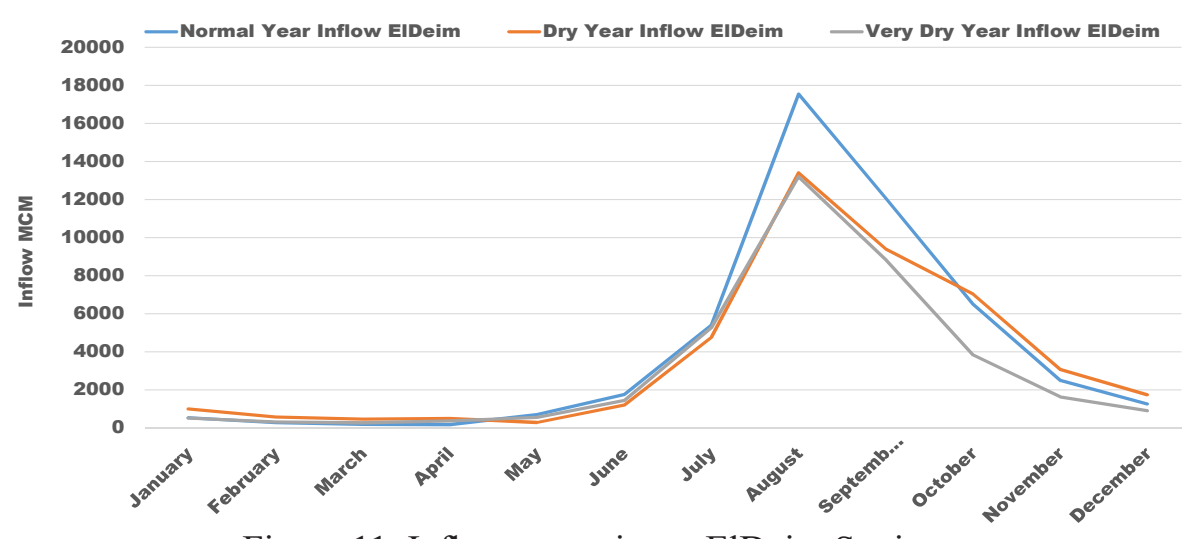

Figure 11. Inflow scenarios at ElDeim Station

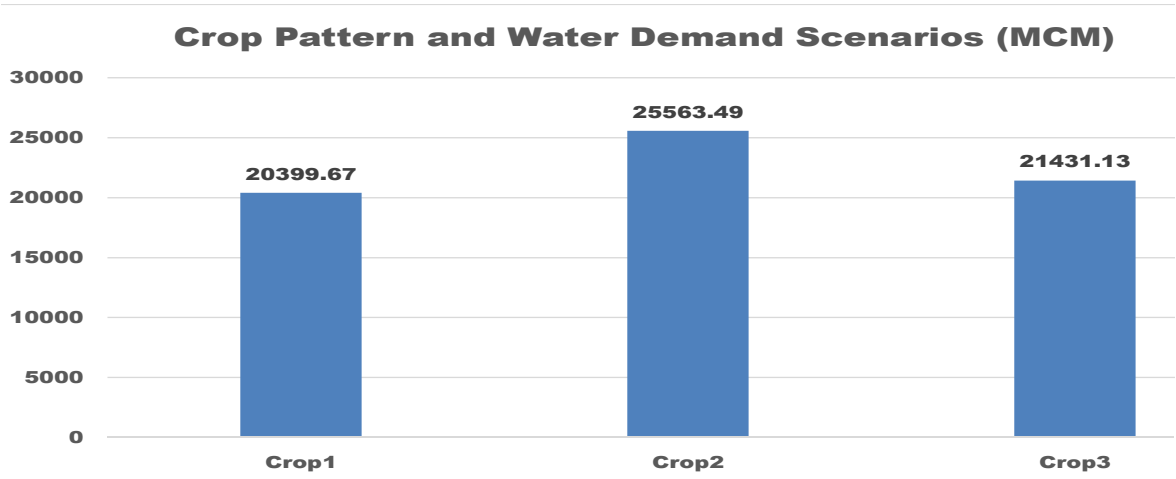

Figure 12. Crop patterns water demand 
each scenario but with different mix percentage. Crop pattern 1, Crop1, has 14.3\% for each crop, crop pattern 2, Crop2, where Sugarcane 39\%, Cotton 28\% and Sesame 22\% have share in crop mix. Crop pattern 3, Crop3, on the other hand has Sugarcane 20\%, Cotton 20\% and Sesame 20\% and rest of crops $10 \%$. Total water demand of each crop pattern is shown in Figure 12.

It is noteworthy that climate change is predicted to reduce the flow at ElDeim by $25 \%$, increase the evaporation and evapotranspiration by $19 \%$. This means in scenarios with consideration of climate change, water demands increase $19 \%$ and inflow at ElDeim will decrease $25 \%$. The results of applying model for obtaining coordinated operation rule curves are shown in Figures 13 to 25.

In figures 13 to 20 rule curves are obtained from optimal coordination of both reservoirs for a typical normal year, dry year and very dry year. Pattern of emptying and filling is totally different

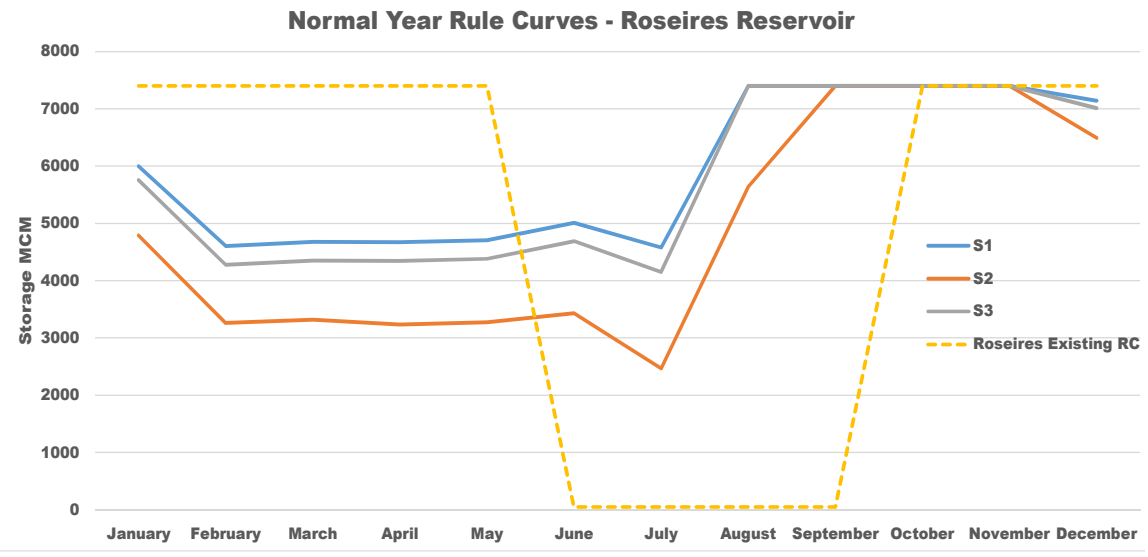

Figure 13. Normal Year Rule Curve for Roseires Reservoir



Figure 14. Normal Year Rule Curve for Sennar Reservoir

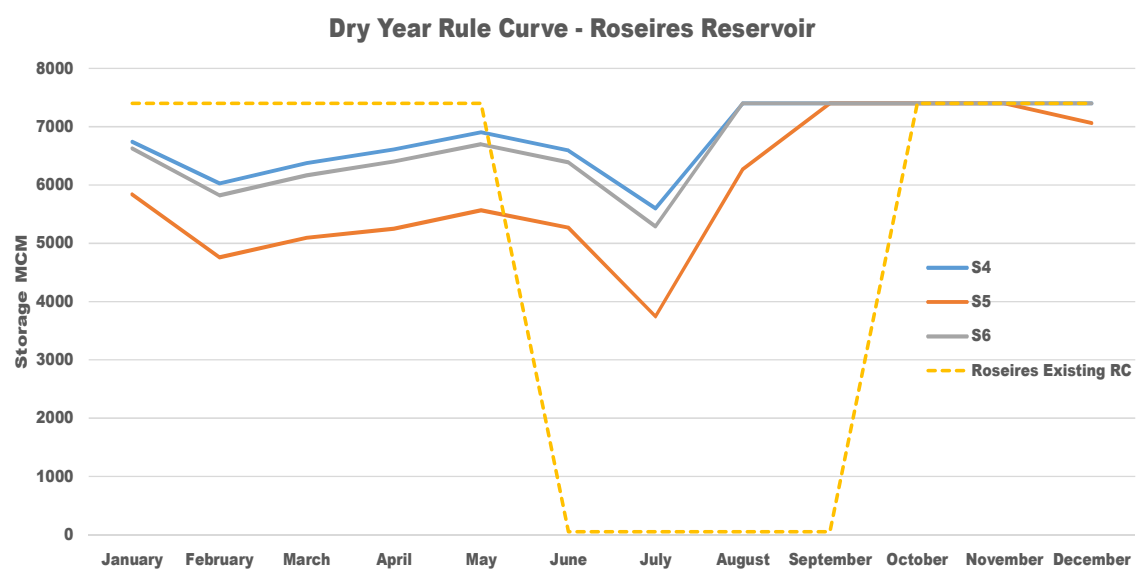

Figure 15. Dry year rule curve for Roseires Reservoir 


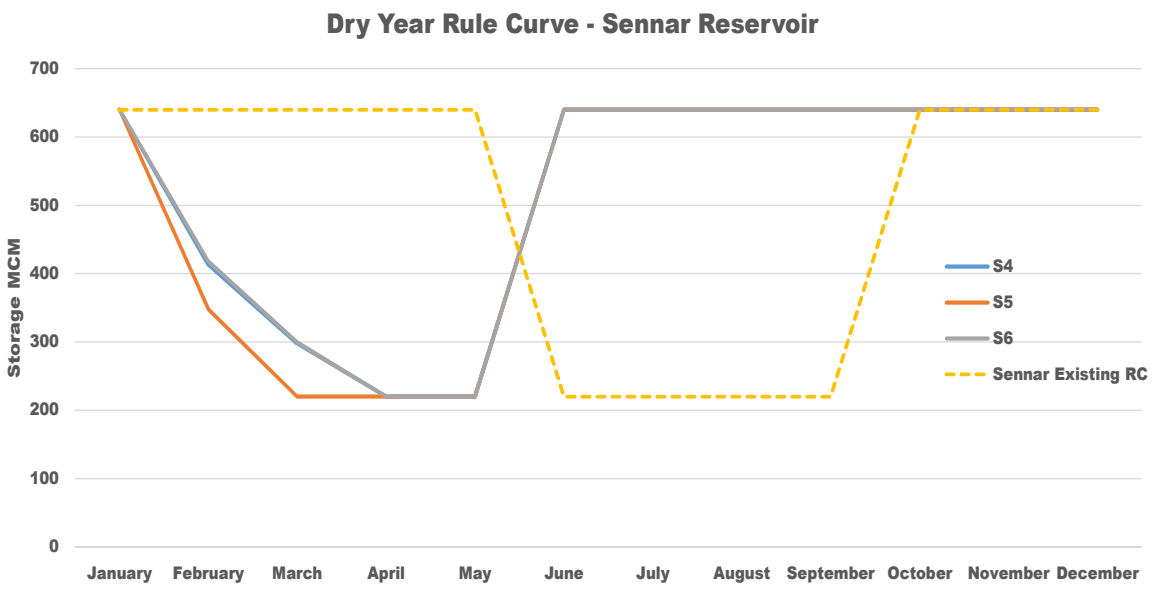

Figure 16. Dry year rule curve for Sennar Reservoir

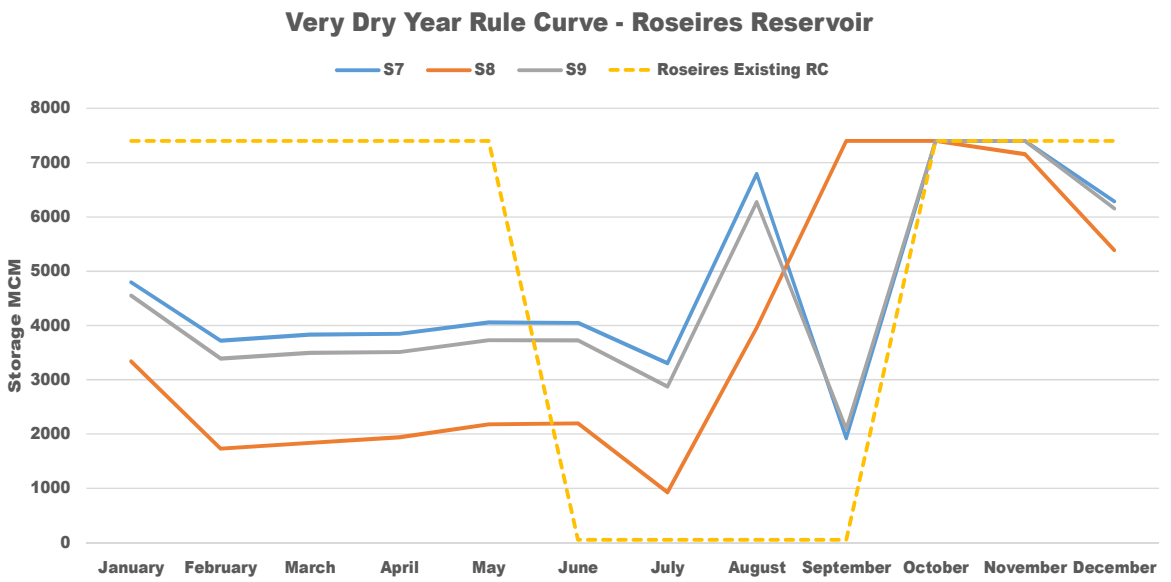

Figure 17. Very Dry year rule curve for Roseires Reservoir

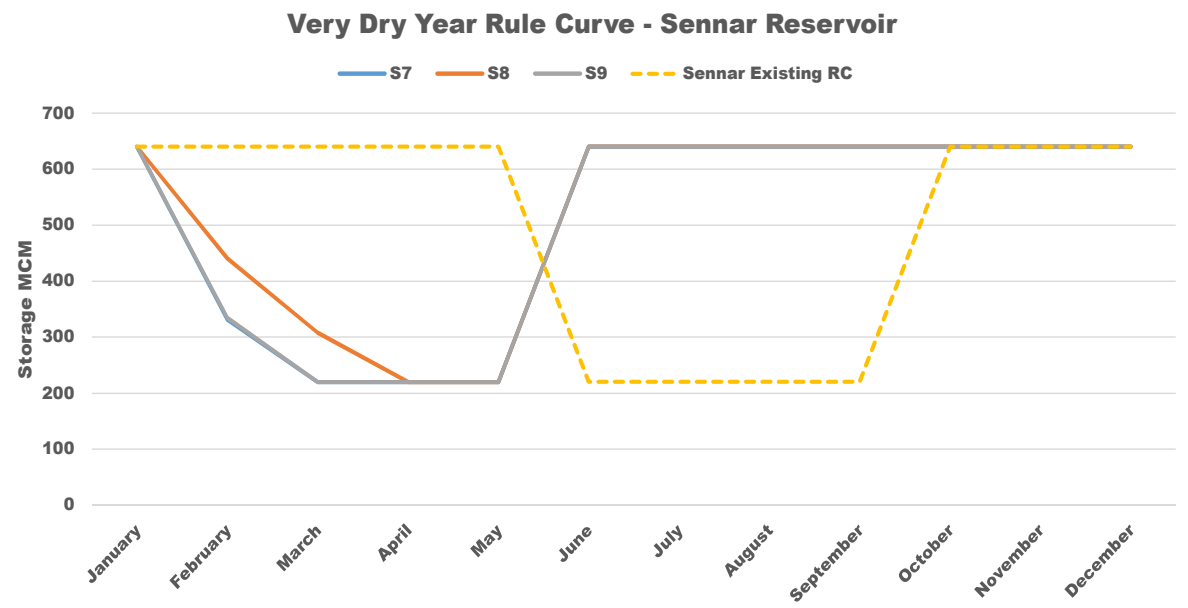

Figure 18. Very Dry year rule curve for Sennar Reservoir

for Roseires from Existing Rule curve as shown in Figures 13, 15, 17 and 19. Aside from different pattern the amount of emptying of the reservoir is different for Roseires reservoir. Rule curve decides to store more water and two times per year emptying and filling is happening. November to February is first emptying, February to June is gentle filling, emptying again more in July, filling in August and September and September till November reservoir is kept full. This pattern is totally different from existing pattern, which is shown in all figures. Pattern of Emptying and Filling of Sennar Dam seems to some extent the same as existing rule curve but with a shift in emptying and filling time. 


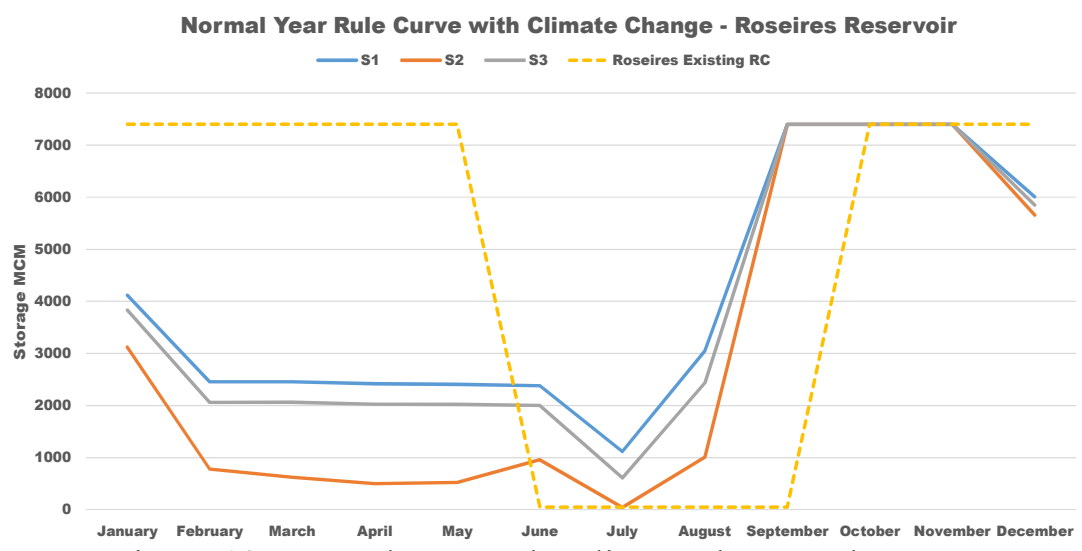

Figure 19. Normal year under climate change rule curve for Roseires Reservoir

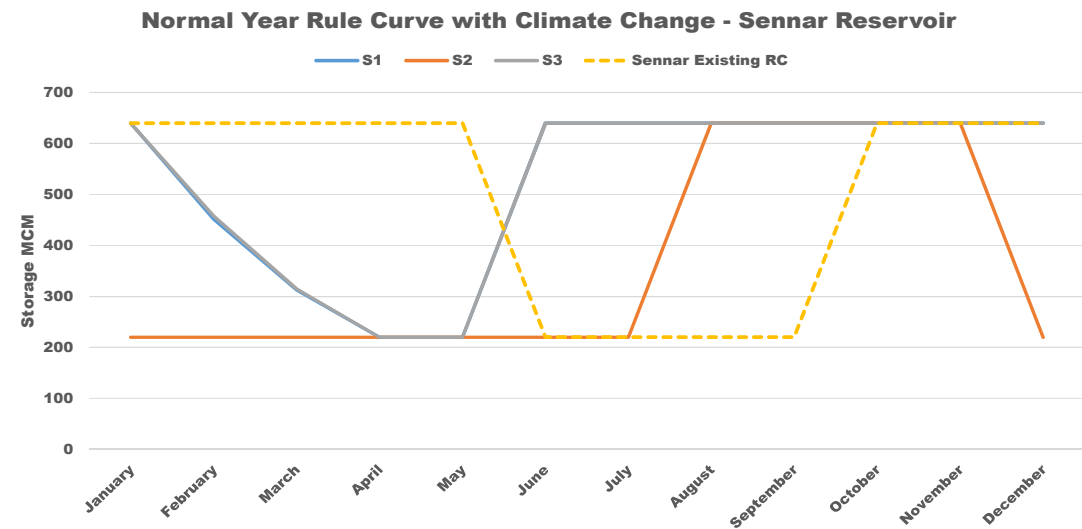

Figure 20. Normal year under climate change rule curve for Sennar Reservoir

Supply Ratio with Climate Change for Roseires Reservoir

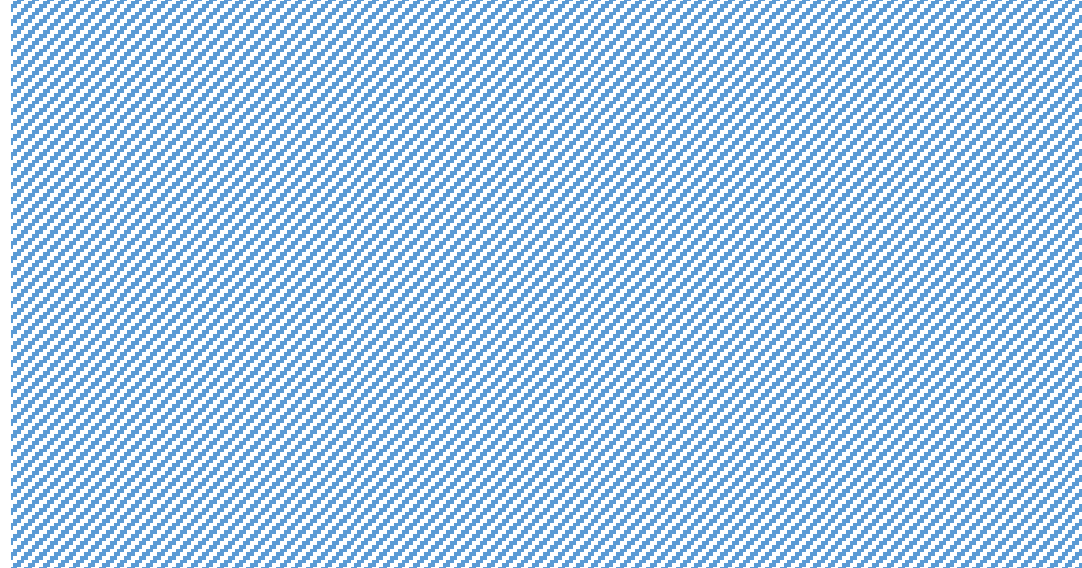

Figure 21. Effect of climate change on water supply from Roseires Reservoir

Emptying starts from January to March, March to May reservoir is kept at minimum level, May and June are filling time and July till December Sennar reservoir is kept full.

Generally these rule curves obtained from optimal coordinating of reservoir operation are totally different from existing rule curves. It indicates that the coordinated optimal rule curves are influenced by the inflow regime, water demand pattern, evaporation and upper-lower limits on reservoir operation on the contrary to existing rule curves that are simple and just empty or fill the reservoir to the minimum and maximum operation level. The amount of emptying the Roseires 


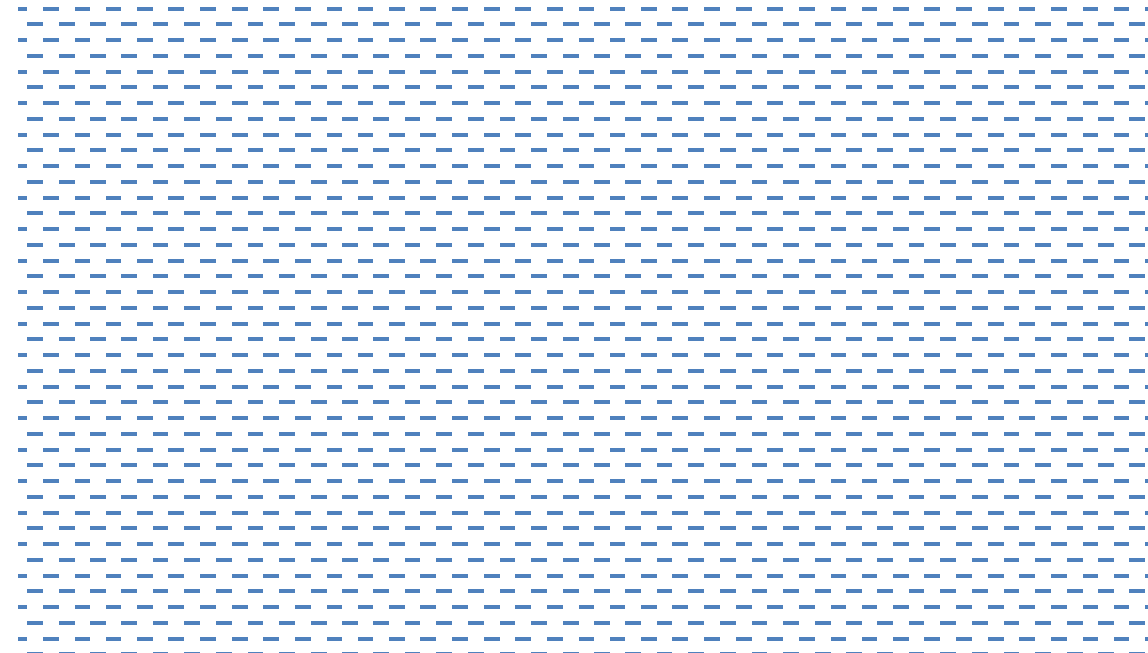

Figure 22. Effect of climate change on water supply from Sennar Reservoir

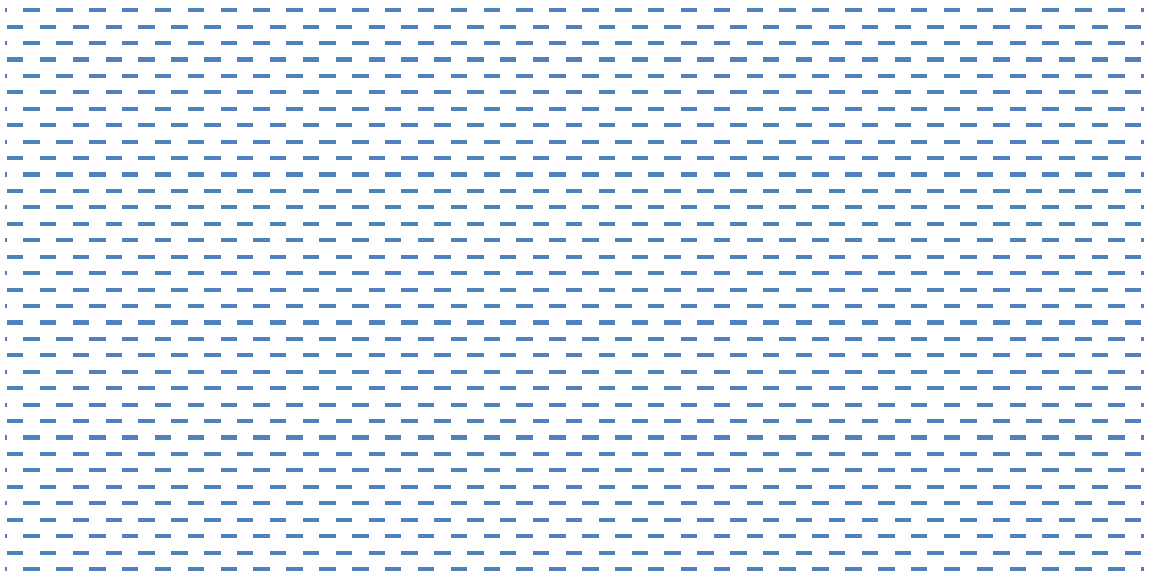

Figure 23. Annual energy generation for each scenario

Water Supply and Demand Report MCM

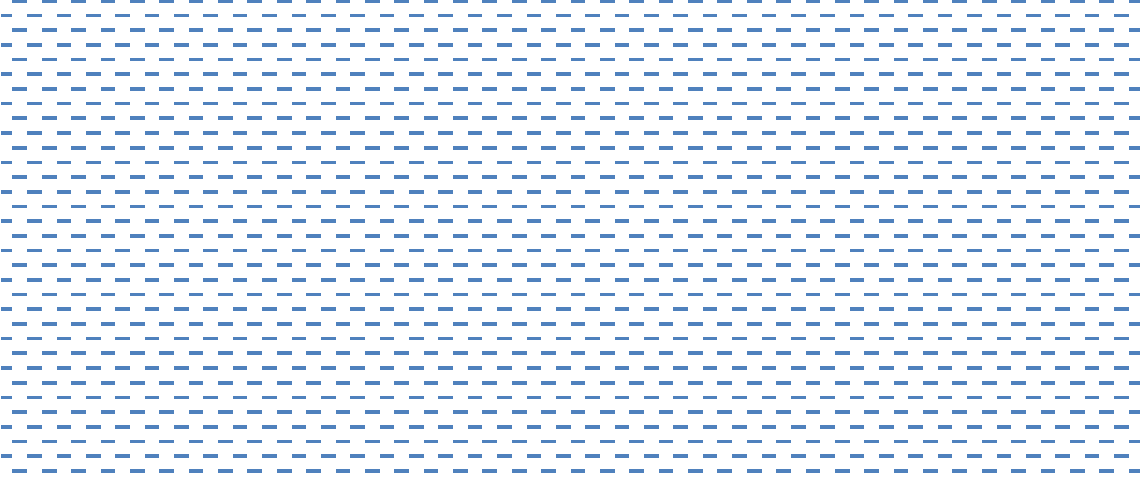

Figure 24. Annual water supply, release and demand

reservoir in dry year is less compared with normal year and it is due the less amount of water in a dry year so water is stored more since spillage also is less probable compared with a normal year. However, for Sennar reservoir as the flow regime becomes dry and dryer rule curves of crop pattern 1 and 3 start to get close to each other.
The same shape of existing rule curve and coordinated rule curve for Sennar reservoir with a shift in emptying and filling time is due to regulated river flow entering Sennar reservoir from Roseires reservoir. This regulated flow is influenced by water demand at Sennar downstream at Gazira and Managil so the shape of rule curve is less 


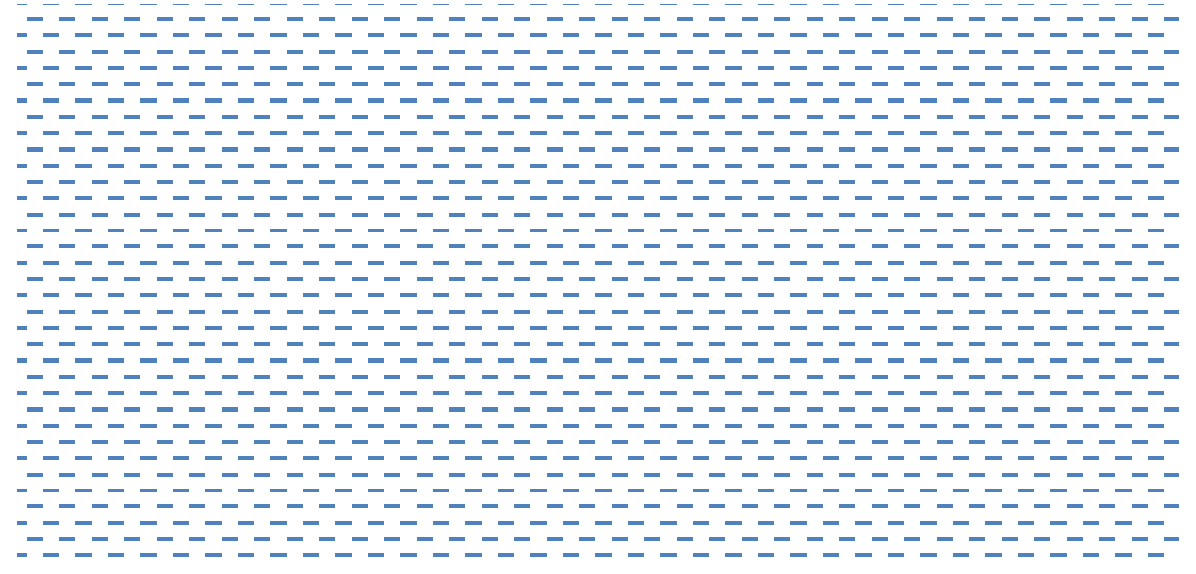

Figure 25. Annual marginal profit for each scenario



Figure 26. ElDeim flow and water demands for all scenarios

fluctuating and complies with demand pattern that empties and fills once per year.

In very dry year condition Roseires reservoir has three empty and filling. It is clear that as inflow conditions become more limited the emptying and filling especially during the high flow time becomes more to make use of high flow time as much as possible. When climate change is happening in normal year for example, Roseires emptying is happening two times and reservoir empties more compared with normal year without climate change to supply the water demands better. Important point about the Sennar reservoir rule curve, is a clear difference between rule curves of crop 1 and crop 3 with crop 2 . It shows that in very limited conditions of flow, water demand shows its effect more in the rule curve. However the shape of rule curve is still following the same shape as other rule curves but with a clear shift.

In conditions without climate change all water demands can be supplied in all crop pattern scenarios. Even the energy generation can be fulfilled up to $1600 \mathrm{GWh}$ per year. With climate change especially in very dry condition shortages will happen even with a coordinated operation, like scenario S8, where crop pattern 2 in very dry condition under climate change. These set of scenarios, S7, S8 and S9, show a very extreme condition in reservoir operation. From water demand point of view scenarios S2, S5 and S8 with climate change also exemplify the critical conditions of water supply, where shortage in supplying water reach up to $67 \%$ in S8, where very dry condition and climate change happens together. The same shortages are occurring in climate change for Sennar reservoir but in scenarios S7, S8 and S9 that belong to very dry condition under climate change.

Monthly hydrograph of flow at ElDeim station has a clear low flow, during December to May, and high flow during July to November. This low flow part has a very critical role in water supply and its shortage as shown in Figure 26. Months November, December, January and June are months that demand is higher than river flow and February till May the flow is also very low even less than Blue Nile River minimum downstream demand. Reservoir storage capacity of Roseires and Sennar is not enough to store water in July 
till October for November till June, especially in very dry years under climate change, when flow reduce by $25 \%$. Figure 25 shows clearly that by coordinated reservoir operation marginal profit can be maintained even in climate change condition. In the worst case that is S8 scenario under climate change where $13 \%$ reduction happens in marginal profit. It is noteworthy that in the same scenario $\mathrm{S} 8,22 \%$ reduction happens for energy generation and its marginal profit. In normal conditions crop pattern 2 is the best option for irrigation schemes. In climate change condition crop pattern 1 is the best option for irrigation schemes.

Conclusion. In this research problem of modeling coordinated reservoir operation for Roseires and Sennar reservoirs is addressed to obtain optimal rule curves to supply the water for irrigation schemes, energy generation and downstream water demands. A multi-period linear optimization model for Roseires-Sennar Dams' reservoirs operation developed that determines the optimal release and storage of water from dams as well as allocation to irrigation schemes and energy generation to have the optimal cumulative marginal profit over the analysis horizon. Model has been validated through equations consistency check after solution, and comparison with observed operation during 1999-2000. 18 scenarios are considered for inflow at ElDeim, water demand, and climate change which address the questions of interest for stakeholders.

Roseires-Sennar Dam System is analyzed for 18 scenarios and coordinated rule curves are obtained for reservoir operation. In normal conditions of flow, crop pattern 2 is the most recommended with more than 11 Billion USD marginal profit and fully supplying the water demand and 1530 GWh energy generation per annum. The rule curves of the Roseires and Sennar reservoirs prescribe a totally different pattern of emptying and filling. Roseires-Sennar Dams system in a normal year under climate change can produce 10.688 Billion USD marginal profit and $1371 \mathrm{GWh}$ per year energy. It shows that model could manage the system performance so that climate change decrease the marginal profit by $3,27 \%$, while inflow is reduced by $25 \%$ and water demands and evaporation increased by $19 \%$. Energy generation under climate change has decreased by $10,5 \%$, which is the most affected sector. In very dry conditions crop pattern 1 is more suitable to be practiced. Impact of GERD can be interpreted as if GERD release the flow to comply with normal year, dry year or very dry year flow at ElDeim station, then with or without climate change what crop patterns are suitable.

\section{References}

1. Abdellatif, M.E.M. (2004). Operation of Roseires and Sennar Dams Using Artificial Neural Network, MSc. Thesis, University of Khartoum, Faculty of Engineering and Architecture, Department of Civil Engineering.

2. Abdo, G., \& Sonbol, M. (2005). Flood Frequency Analysis for the Eastern Nile. FRIEND/ NILE Conference, Sharm El Sheikh, Egypt.

3. Basheer, M., Wheeler, K.G., Ribbe, L., Majdalawi, M., Abdo, G., \& Zagona, E.A. (2018). Quantifying and evaluating the impacts of cooperation in transboundary river basins on the WaterEnergy-Food nexus: The Blue Nile Basin. Science of the Total Environment, 630, 1309-1323.

4. Belachew, A., and Mekonen, Z. (2014). Eastern Nile Basin Water System Simulation Using Hec-ResSim Model. International Conference on the Hydroinformatics. CUNY Academic Works. 8-1-2014.

5. Bower, B.T., Hufschmidt, M.M., \& Reedy, W.W. (1962), Operating procedures: Their role in the design of water-resources systems by simulation analyses, in Design of Water-Resource Systems. A. Maass (Ed.). Cambridge: Harvard Univ. Press.

6. Cai, X, McKinney, D.C.,\& Lasdon, L.S. (2003). Integrated hydrologic-agronomic-economic model for river basin management, Journal of water resources planning and management, 129(1), 4-17.

7. Cai, X, McKinney, D.C., \& Lasdon, L.S. (2001). Piece-by-piece approach to solving large nonlinear water resources management models, Journal of Water Resources Planning and Management, 127(6), 363-368

8. Cai, X, McKinney, D.C.,\& Lasdon, L.S. (2001).Solving nonlinear water management models using a combined genetic algorithm and linear programming approach, Advances in Water Resources 24(6), 667-676.

9. Doulgeris, C., Pantazis, G., Papadimos, D., \& Papamichail, D. (2015) Water allocation under deficit irrigation using MIKE BASIN model for the mitigation of climate change. Irrigation Science, 33(6), 469-482.

10. Close, A., Haneman, W.M., Labadie, J.W., \& Loucks, D.P. (Chair), Lund, J.R., McKinney, D.C. and Stedinger J.R. (2003). A Strategic Review of CALSIM II and its Use for Water Planning, 
Management, and Operations in Central California. California Bay Delta Authority Science Program, Association of Bay Governments. Oakland:California.

11. Elamin, M., (2006). Hydro-electric Power Technical and Economical Features. Master's Thesis. Khartoum: University of Khartoum.

12. GAMS. (2021). General Algebraic Modeling System.Retrieved from: www.gams.com

13. Gelete, G., Gokcekus, H., \& Gichamo, T. (2020). Impact of climate change on the hydrology of

Blue Nile basin, Ethiopia: A review. Journal of Water and Climate Change, 11(4), 1539-1550.

14. Klemes, V. (1977). Value of information in reservoir optimization. Water Resources Research, $13(5), 850-857$.

15. Karnatapu, L.K., Annavarapu, S.P., \& Nanduri, U.V. (2020). Multi-Objective Reservoir Operating Strategies by Genetic Algorithm and Nonlinear Programming (GA-NLP) Hybrid Approach.

J. Inst. Eng. India Ser. A., Vol. 101., Issue 1., 105-115.

16. Loucks, D.P. (1967) Computer models for reservoir regulation. Reprint 534. American Society of Civil Engineers Conference Reprint, 16-20.

17. Loucks, D.P., Stedinger, J.R. \& Haith, D. A. (1981). Water Resources Systems Planning and Analysis. Englewood Cliffs : Prentice-Hall.

18. Lucas, E.C.G. (2018). Application of HEC-ResSim in the study of new water sources in the Panama Canal. Journal of Applied Water engineering and Research, Vol. 6, Issue 3, 236-250.

19. Maass, A., Hufschmidt, M.M., Dorfman R., Thomas, H.A. Jr, Marglin, S.A. and Fair G.M. (1962). Design of Water-Resource Systems. Cambridge : Harvard Univ. Press.

20. Manne, A.S. (1962). Product-mix alternatives: flood control electric power and irrigation. International Economic Review. 3(1):3\&59.

21. McCartney, M.P., Ibrahim, Y.A., Sileshi, Y., \& Awulachew, S.B. (2009). Application of the Water Evaluation and Planning (WEAP) Model to Simulate Current and Future Water Demand in the Blue Nile, Intermediate Results Dissemination Workshop, 78-88.

22. Ngo, L.A, Masih I., Jiang, Y., \& Douven, W. (2016) Impact of reservoir operation and climate change on the hydrological regime of the Sesan and Srepok Rivers in the Lower Mekong Basin, Climate Change, 1-13.

23. Nile Basin Initiative, (2017). Retrieved from: https://nilebasin.org/

24. Plusquellec, H., (1990). The Gezira Irrigation Scheme in Sudan, Objective, Design and Performance, World Bank Technical Paper. No 120. Washington D.C.

25. Oliveira, R., \& Loucks, D.P. (1997). Operating rules for multireservoir systems. Water Resources Research, Vol. 33, No. 4, 839-852.

26. Ortiz-Partida, J.P., Lane, B.A., \& Sandoval-Solis, S. (2016) Economic effects of a reservoir re-operation policy in the Rio Grande/Bravo for integrated human and environmental water management. Journal of Hydrology: Regional Studies, Vol. 8, 130-144.

27. Pallottino, S., Sechi, G.M., \& Zuddas, P. (2005). A DSS for Water Resources Management under Uncertainty by Scenario Analysis, Environmental Modelling and Software 20(8), 1031-1042.

28. Rippl, W. (1883). The capacity of storage-reservoirs for water-supply. (Including plate). Minutes of the proceedings of the institution of civil engineers, 270-278.

29. Schluter, M., Savitsky, A.G., McKinney, D.C., \& Lieth, H. (2005). Optimizing long-term water allocation in the Amudarya River delta: a water management model for ecological impact assessment. Environmental Modelling \& Software, 20, 529-545.

30. Seifi, A., \& Hipel, K.W. (2001), Interior-Point Method For Reservoir Operation With Stochastic Inflows. J. Water Resour. Placnn. Manage. No. 1(127), 48-57.

31. Shafer, J,. \& Labadie, J. (1978). Synthesis and calibration of a river basin water management model, Completion Report No. 89, Colorado Water Resources Research Institute, Colorado State University, Ft. Collins.

32. SMEC. (2021). Retrieved from: http://www.smec.com/70years/portfolio/roseires-dam-heightening/ 33. Thomas, H. A., Jr., \& Burden, R. P. (1963). Operations Research in Water Quality Management, Engineers, Vol. 71, 270-278. Harvard University.

34. Thomas, H. A., Revelle, Jr., \& Revelle, R. (1966). On the efficient use of the high Aswan Dam for hydropower and irrigation. Management Science. 12(8): B296-B311.

35. Roseires Dam, (2020). Wikipedia, www.wikipedia.com

36. You, J., \& Cai, X. (2008) Hedging rule for reservoir operations: A theoretical analysis. Water Resources Research, vol. 44, W01415, 1-9. 


\section{Тоайба Заін Еабдін Саад Омер, Сіддіг Е. Ахмед, Акбар Карімі Оптимальна експлуатація каскаду багатоцільових водосховищ на прикладі водосховищ Розейрез та Сеннар}

Анотація. Система дамб Розейрез-Сеннар (СДРС) у нижній частині річки Блакитний Ніл відіграє життєво важливу роль у забезпеченні водою систем зрочення Судану. Існуючі диспетчерські графіки експлуатації для цих систем були розроблені і впроваджені в 1925 і 1966 років для водосховищ Сеннар і Розейрез відповідно. Впровадження нових зрошувальних систем, підтверджений вплив зміни клімату на річку Блакитний Ніл і розвиток територій вище за течією в Ефіопії, а також підвищення дамби Розейрез з висоти 480 до 490 м над рівнем моря показали, що СДРС втрачає свою ефективність з точки зору повного задоволення потреб в постачанні водою. У літературних джерелах розглядається моделювання дамб Розейрез та Сеннар з метою знайти найкращі скоординовані диспетчерські графіки управління за умов обмеженої кількості правил експлуатаиії водосховищ, які мінімізують вплив розбудови територій, зростання попиту на воду та зміни клімату на водопостачання для забезпечення різноманітних потреб на річиі Блакитний Ніл. Такі рішення є локально оптимальними, оскільки вони не розглядають потенціал зберігання та перенесення об'ємів води водосховищами, що дає змогу перенести неоптимальні (локально оптимальні) рішення на інші часові періоди планування та створити дефііцт в інші часові періоди. Таким чином, метою даного дослідження є знайти оптимальні координуючі правила експлуатаиіі дамб Розейрез та Сеннар за допомогою нелінійної багатоперіодної оптимізачійної моделі, яка враховуює зміни клімату, режим стоку та потребу у воді. Ефективність моделі підтверджена практично під час спостережень за роботою водосховищу період з листопада 1999 року до травня 2000 року. Проаналізовано вісімнадиять сиенаріїв, які охоплюють нормальний, сухий та дуже сухий режими стоку, а також запропоновано три моделі систем землеробства та проаналізовано вплив зміни клімату.

Результати показують, що в звичайних умовах стоку найбільш рекомендованою є система землеробства 2 з граничним прибутком понад 11 мільярдів доларів США та повним забезпеченням потреби у воді та виробництвом енергії 1530 ГВт-год на рік. Скоординовані диспетчерські графіки експлуатаиії водосховищ мають зовсім іншу схему спорожнення та заповнення порівняно з існуючими. Диспетчерські графіки змінюються в залежності від водного режсиу водосховищ, що доводить те, що зміна умов системи впливає на оптимальні правила роботи. Порівняння граничного прибутку з сиенарієм моделювання врожаю 2 показує, що за умов трьох різних сиенаріїв щодо забезпеченості опадами - нормального, сухого і дуже посушливого років оптимізачійна модель для різних періодів може забезпечити граничний прибуток вище 11 мільярдів доларів США, скажімо, 11 050, 11056 і 11,042 мільярдів доларів відповідно, що показує надійність моделі в роботі з будьякими умовами $i$ забезпечує гарантований прибуток. Однак у иих трьох умовах диспетчерські графіки для водосховища Розейрес відрізняються, тоді як диспетчерські графіки для водосховища Сеннар залишаються майже однакові. Якщо виключити вплив клімату, то модель може повністю забезпечити потреби у воді в будь-яких умовах водо забезпечення. Однак на надійність водопостачання у всіх запропонованих моделях землеробства виливає зміна клімату. Система дамб РозейресСеннар за типовий рік в умовах зміни клімату може виробляти 10,688 млрд доларів граничного прибутку та 1371 ГВт-год енергї̈ на рік.

Це показує, щьо модель дає можливість керувати роботою системи коли зміна клімату знижує граничний прибуток на 3,27\%, тоді як притік води зменшується на $25 \%$, а потреба у воді та випаровування збільшується на 19\%. Виробництво енергії в умовах зміни клімату зменшилося на 10,5\%, що є найбільш уразливим сектором. Запропоновані системи землеробства 2 і 3 не підходять для умов зміни клімату, оскільки дефіиит води може становити до 65\% у разі дуже посушливого року з урахуванням кліматичних змін. У дуже посушливих умовах краще використовувати систему землеробства 1.

Ключові слова: дамба Розейрес - Сеннар, експлуатайія водосховища, оптимальна координація, багатоиільове водосховище, довгострокове планування

\section{Тоайба Заин Эабдин Саад Омер, Сиддиг Э. Ахмед, Акбар Карими Оптимальная эксплуатация каскада многоцелевых водохранилищ на примере водохранилищ Розейрез и Сеннар}

Аннотация. Система дамб Розейрез-Сеннар (СДРС) в нижней части реки Голубой Нил играет жизненно важную роль в обеспечении водой систем орошения Судана. Существуюшие диспетчерские графики эксплуатации для этих систем были разработаны и внедрены в 1925 и 1966 годах для водохранилищ Сеннар и Розейрез соответственно. Внедрение новых оросительных систем, подтвержденное влияние изменения климата на реку Голубой Нил и развитие территорий выше по течению в Эфиопии, а также повышение дамбы Розейрез с высоты 480 до 490 м над уровнем моря показали, что СДРС теряет свою эффективность с точки зрения полного удовлетворения потре- 
бностей в снабжении водой. В литературных источниках рассматривается моделирование дамб Розейрез и Сеннар с изелью найти лучше скоординированные диспетчерские графики управления при условии ограниченного количества правил эксплуатаџии водохранилищ, минимизирующих влияние развития территорий, роста спроса на воду и изменения климата на водоснабжение для обеспечения разнообразных потребностей на реке Голубой Нил. Такие решения локально оптимальны, поскольку они не рассматривают потенциал хранения и переноса объемов воды водохранилищ, что позволяет перенести неоптимальные (локально оптимальные) решения на другие временные периоды планирования и создать дефицит в другие временные периоды. Таким образом, ичелью данного исследования является найти оптимальные координирующче правила эксплуатации дамб Розейрез и Сеннар с помощьью нелинейной многопериодной оптимизационной модели, учитьвающей изменение климата, режим стока и потребность в воде. Эффективность модели подтверждена практически во время наблюдений за работой водохранилища в период с ноября 1999 года по май 2000 года. Проанализированы восемнадцать сиенариев, охватывающцих нормальный, сухой и очень сухой режимы стока, а также предложены три модели систем земледелия и проанализировано влияние изменения климата.

Результаты показывают, что в обычных условиях стока наиболее рекомендована система земледелия 2 с предельной прибылью более 11 миллиардов долларов США и полным обеспечением потребности в воде и производством энергии 1530 ГВт-ч в год. Скоординированные диспетчерскиеграфики эксплуатации водохранилищ имеют совершенно иную схему опорожнения и заполнения по сравнению с существуюшими. Диспетчерские графики изменяются в зависимости от водного режима водохранилиш, что доказывает, что изменение условий системы влияет на оптимальные правила работы. Сравнение предельной прибыли со сиенарием моделирования урожая 2 показывает, что в условиях трех разных сиенариев по обеспечению осадками - нормального, сухого и очень засушливого лет оптимизационная модель для разных периодов может обеспечить предельную прибыль свылие 11 миллиардов долларов США, скажем, 11050, 11011,042 миллиарда долларов соответственно, что показывает надежность модели в работе с любыми условиями и обеспечивает гарантированную прибыль. Однако в этих трех условиях диспетчерские графики для водохранилища Розейреса отличаются, тогда как диспетчерские графики для водохранилища Сеннар остаются почти одинаковыли. Если исключить влияние климата, модель может полностью обеспечить потребности в воде в любых условиях водоснабжения. Однако на надежность водоснабжения во всех предлагаемых моделях земледелия влияет изменение климата. Система дамб РозейресСеннар за типичный год в условиях изменения климата может производить 10,688 млрд. долларов предельной прибыли и 1371 ГВт-ч энергии в год.

Это показывает, что модель позволяет управлять работой системы, когда изменение климата снижает предельную прибыль на 3,27\%, тогда как приток воды уменьшается на 25\%, а потребность в воде и испарение увеличивается на 19\%. Производство энергии в условиях изменения климата уменьшилось на 10,5\%, что является наиболее уязвимым сектором. Предлагаемые системы земледелия 2 и 3 не подходят для условий изменения климата, поскольку дефиичт водь может составлять до 65\% в случае очень засуиливого года с учетом климатических изменений. В очень засушливых условиях лучше использовать систему земледелия.

Ключевые слова: дамба Розейрес - Сеннар, эксплуатаџия водохранилища, оптимальная координация, многочелевое водохранилище, долгосрочная пласировка 